\title{
Analysis of genetic variation in different banana (Musa species) variety using random amplified polymorphic DNAs (RAPDs)
}

\author{
Pankaj Kumar Jain ${ }^{1}$, Mohan Lal Saini ${ }^{2 \star}$, Hardik Pathak ${ }^{1}$ and Virendra Kumar Gupta ${ }^{1}$ \\ ${ }^{1}$ Departmant of Biotechnology, Mahatma Gandhi Institute of Applied Sciences, Jaipur, India. \\ ${ }^{2}$ Biotechnology Lab, Department of Botany, UOR, Jaipur, India.
}

Accepted 27 July, 2007

\begin{abstract}
The banana (Musa acuminata Colla) is considered as an important crop plant due to its high economic value as good dietary source. Here, we analyze the genetic relationship of four different banana varieties that are cultivated in south India. Random amplified polymorphic DNAs (RAPDs) fingerprinting of these banana varieties (Grand Naine, Red Banana, Nendran and Rasthali) carried out by three primers (OPA-19, OPB-18, OPD-16) led to DNA amplification. $43.47 \%$ of the amplification products were monomorphic (common to all the genotypes), whereas $30.43 \%$ were unique, but only $26.08 \%$ revealed the relationship between these genotypes.
\end{abstract}

Key words: DNA fingerprinting, RAPD analysis, Taq DNA polymerase, primers.

\section{INTRODUCTION}

Banana is one of the important fruit and vegetable crops of India that is also known as universal fruit crop of India. Banana is a tropical crop par excellence grown in all tropical and subtropical region of the world. Very few cultivars satisfy standards for fruit quality and clonal fidelity; thus, accurate verification of cultivar identity for checking propagation material and patent protection is important. Traditional methods for testing genetic variability in fruit crops are based on morphological or timeconsuming physiological assays (Scheliro et al., 2001). But the presently exist biochemical and molecular techniques are more advance to improve these fruit crops. (Williams et al., 1993; Smith et al., 1994; Welsh et al., 1995; Rafalski et al., 1996). Random amplified polymorphic DNAs (RAPDs) have been used reliably as molecular markers in cultivar characterization for Malus species L. (apple) (Koller et al., 1993; Yae and Ko, 1995), Vitis vinifera (L.) Kuntze (grapes) (Büscher et al., 1993; Qu et al., 1996), Citrus limon Burm. f. (lemon) (Deng et al., 1995), Prunus persica L. Batch (peach) (Chaparro et al., 1994; Warburton and Bliss, 1996), Prunus species (plum) (Ortiz et al., 1997), Pyrus cummunis L. (Scheliro et al., 2001) and Oryza sativa L. (rice) (Shivapriya and Shailaja, 2006).

*Corresponding author. E-mail: monaphd2005@yahoo.co.in.
RAPDs have the advantage that the material is processed by an efficient and inexpensive technique without requiring prior knowledge of the genome (Bhat and Jarret, 1995). RAPD assay has the advantage of being easy to use, requiring very small amount of genomic DNA without the need for blotting and radioactive detection (Cipriani et al., 1996; Atienzar et al., 2000), and are moderately reproducible. In this research, an attempt has been made to fingerprint and study their genetic relationship using RAPD markers, which could be very helpful for germplasm management, crop improvement and plant varietals rights.

\section{MATERIALS AND METHODS}

The leaves of different Musa varieties (Grand Naine, Red Banana, Nendran and Rasthali) were obtained from the horticulture farm of the University of Agricultural Sciences, GKVK, Bangalore. Good quantities of high quality DNA was obtained by cetyl-trimethyl ammonium bromide (CTAB) method as described by Gawal and Jarret (1991). These DNA samples were further diluted and maintained at $-20^{\circ} \mathrm{C}$ for RAPD analysis. The PCR reaction was carried out in a final volume of $25 \mu \mathrm{l}$ reaction containing $30 \mathrm{ng}$ of template DNA, dNTPs (175 mM each), Taq DNA polymerase (1 unit), $\mathrm{MgCl}_{2}(1.5 \mathrm{mM})$ and 5 pmoles of primer in $25 \mu \mathrm{l}$ of $1 \times$ PCR buffer. The PCR mixture was overlaid with a drop of mineral oil. A MJ research thermal cycler (PTC-100) was programmed for initial denaturation at $94^{\circ} \mathrm{C}$ for $1 \mathrm{~min}$, primer annealing at $35^{\circ} \mathrm{C}$ for $1 \mathrm{~min}$, primer extension at $72^{\circ} \mathrm{C}$ for $2 \mathrm{~min}$, and final extension of $10 \mathrm{~min}$ at $72^{\circ} \mathrm{C}$. Moreover, the PCR reactions were repeated using the same 
Table 1. Total number of amplified fragments and number of polymorphic bands generated by PCR using three selected primers.

\begin{tabular}{|l|c|c|c|c|c|}
\hline $\begin{array}{c}\text { Nucleotide } \\
\text { Primer }\end{array}$ & $\begin{array}{c}\text { Shared } \\
\text { sequence (5'-3') }\end{array}$ & $\begin{array}{c}\text { Unique Polymorphic } \\
\text { Polymorphic bands }\end{array}$ & $\begin{array}{c}\text { Monomorphic } \\
\text { bands }\end{array}$ & Total \\
\hline OPA -19 & CAAACGTCGG & 4 & 0 & 3 & 7 \\
OPB -18 & CCACAGCAGT & 1 & 4 & 3 & 8 \\
OPD -16 & AGGGCGTAAG & 1 & 3 & 4 & 8 \\
\hline
\end{tabular}

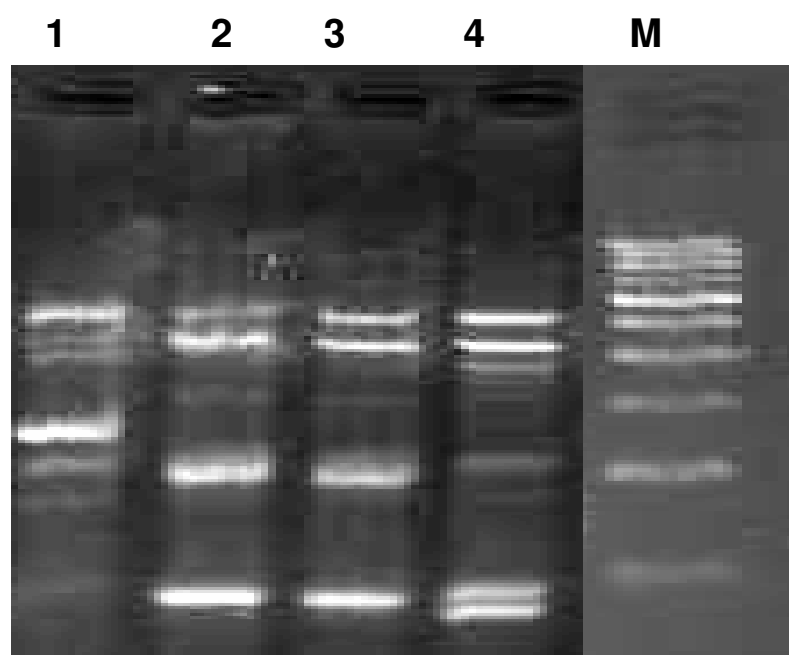

Figure 1. RAPD profile of four banana varieties using OPB-18 primer. Lane 1 - 4: RAPD profile of Banana varieties (1) Grand Naine, (2) Red Banana, (3) Nendran and (4) Rasthali. Lane M: 500 bp DNA ladder.

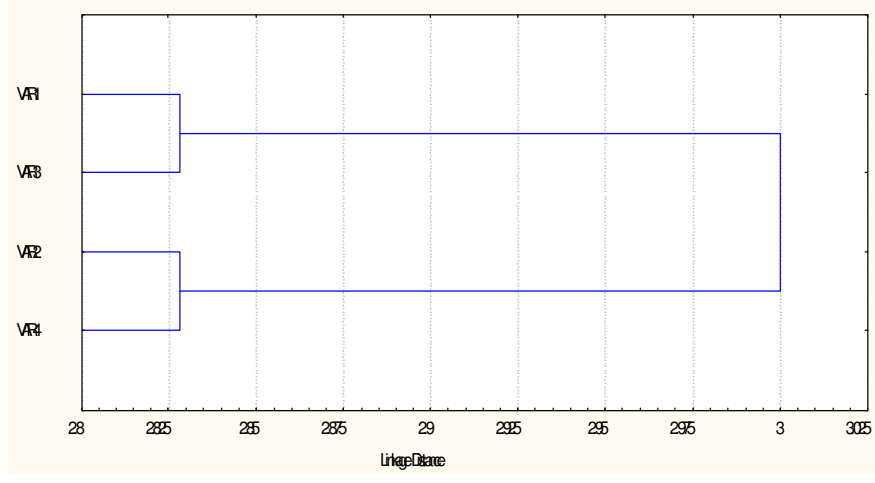

Figure 2. Dendrogram of four varieties of banana. (VR1) Grand Naine, (VR2) Red Banana, (VR3) Nendran and (VR4) Rasthali.

conditions to check the repeatability of amplified products. To select primers (Table 1), that can amplify informative RAPD fragments, PCR was carried out to screen 10 random primers of arbitrary sequence (Operon technologies Limited). Out of 10 primers screened, 3 primes producing strong, intense and unambiguous bands. These were further used for estimating the genetic diversity among the varieties of banana. Reproducibility of these selected primers was tested by repeating the PCR amplification for at least two times under the same amplification conditions.
Table 2. Genetic dissimilarity of 4 verities of Banana as Obtained from RAPD markers.

\begin{tabular}{|l|c|c|c|c|}
\hline & VAR 1 & VAR 2 & VAR 3 & VAR 4 \\
\hline VAR 1 & 0 & & & \\
VAR 2 & 3.31 & 0 & & \\
VAR 3 & 2.82 & 3.0 & 0 & \\
VAR 4 & 3.6 & 2.82 & 3.33 & 0 \\
\hline
\end{tabular}

VAR $1=$ Grand Naine, VAR2 $=$ Red Banana, VAR3 $=$ Nendran and VAR4 $=$ Rasthali.

\section{RESULTS AND DISCUSSION}

Out the amplification products recorded, $43.47 \%$ were monomorphic, common to all the genotypes. Whereas, $30.43 \%$ were unique, and only $26.08 \%$ revealed the relationship between these genotypes. Among the selected primers OPB-18 (Figure 1) produced maximum number of polymorphic 4 bands followed by OPA-19 and OPD-16. The pool of primers yielded reasonable number of polymorphic fragments for all the genotypes examined.

RAPD bands were manually scored from the gel profile, ' 1 ' for the presence and ' 0 ' for the absence of band and the binary data generated from all the profiles, were used for statistical analysis. The dissimilarity matrix was computed using Squard Euclidean Distance (SED) that estimated all pair wise difference in the amplification product. The dendrogram (Figure 2) was constructed by Ward's method of clustering using minimum variance algorithm. Cluster analysis revealed the 4 genotypes examined on the dendrogram with Grandnaine and Rasthali spanning the extreme. The genetic dissimilarity value ranges from 2.82 to $3.6 \%$ was observed. The highest dissimilarity $3.6 \%$ was detected between genotypes Red banana and Rasthali and the least $2.23 \%$ between genotypes Nendran and Rashali (Table 2).

India has immense wealth of banana germplasm that ranks as second most important fruit crop of the country both in area and production. Its global share in the international market is almost negligible due to polyclonal system of cultivation. From the above study, we concluded that RAPD is reliable, rapid and inexpensive screening method to discriminate the Musa genotype. RAPD analysis also revealed genetic diversity among these investigated species, which may be beneficial to crop improvement and the detection of gene flow between species. Furthermore, this technique is less restricting 
than other techniques like RFLPs (no hybridization and no use of radioisotopes), and therefore is more convenient for use in research centers in developing countries.

\section{ACKNOWLEDGMENT}

We wish to thank Head, Department of Biotech, M.G.I.S, and for his encouragement and support.

\section{REFERENCES}

Atienzar F, Evenden A, Jha A, Savva D, Depledge M (2000). Optimized RAPD analysis generates high-quality genomic DNA profiles at high annealing temperatures. Biotechniques. 28: 52-54

Bhat KV, Jarret RL (1995). Random amplified polymorphic DNA and genetic diversity in Indian Musa germplasm, Genet. Res. Crop Evol. 42: 107-118.

Büscher N, Zyprian E, Blaich R (1993). Identification of grapevine cultivars by DNA analyses: pitfalls of random amplified polymorphic DNA techniques using 10-mer primers. Vitis 32: 187-188.

Chaparro E, Werner DJ, O'Malley D, Sederoff RR (1994). Targeted mapping and linkage analysis of morphological isozyme, and RAPD markers in peach. Theor. Appl. Genet. 83: 194-200.

Cipriani G, Bella R, Testolin R (1996). Screening RAPD primer for molecular taxonomy and cultivar fingerprinting in genus Actinidia. Euphytica 90: 169-174.

Deng ZN, Gentile A, Nicolosi E, Domina E, Vardi A, Tribulato E (1995). Identification of in vitro and in vivo lemon mutants with RAPD markers. J Hort Sci 70: 117-125.

Gawal NJ, Jarret RL (1991). Cytoplasmic genetic diversity in banana and plantain. Euphytica 52:19-23.

Koller B, Lehmann A, Mcdermott JM, Gessler C (1993). Identification of apple cultivars using RAPD markers. Theor. Appl. Genet. 85: 901904.

Ortiz A, Renaud R, Calzada I, Ritter R ( 1997). Analysis of plum cultivars with RAPD markers. J. Hortic. Sci. 72: 1-9.

Qu X, Lu J, Lamikanra O (1996). Genetic diversity in muscardine and American bunch grapes based on Randomly Amplified polymorphic DNA (RAPD) analyses. J. Am. Soc. Hortic. Sci. 121: 1020-1023.
Rafalski JA, Vogel JM, Morgante M, Powell W, Andre C, Tingey SV (1996). Generating and using DNA markers in plants. In: Birren B and Lai (eds), Nonmammalian genomic analysis, Academic Press, USA, pp. 75- 34 .

Scheliro E, Predieri S, Bertaccini A (2001). Use of random amplified DNA analysis to detect genetic variation in pyrus species.Plant Mol. Bio. Rep. 19: 271a-h.

Shivapriya M, Shailaja H (2006). Detection of genotype specific fingerprint and molecular diversity of selected Indian local and landrace of rice (Oryza Sativa L.) using DNA marker. Ind. J. Genet. 66(1): 1-5.

Smith JSC, Williams GK (1994). Arbitrary primed mediated fingerprinting in plants:case studies in plant breeding, taxonomy and phylogeny. In: Schierwater B, Street B, Wagner GP, de Salle R (eds), Molecular Ecology and Evolution: Approaches and Applications, Birkhäuser Verlag, Basel, pp. 5-15.

Warburton ML, Bliss FA (1996). Genetic diversity in peach (Prunus persica L. Batch) revealed by Randomly Amplified Polymorphic DNA (RAPD) markers and compared to imbreeding coefficients. J. Am. Soc. Hortic. Sci. 121: 1012-1019.

Welsh J, Ralph D, McClelland M (1995). DNA and RNA fingerprinting using arbitrarily primed PCR. In: Innis MA, Gelfand DH, Sninsky JJ, (eds), PCR Strategies, Academic Press, San Diego, pp 249-276.

Williams JGK, Hanafey MK, Rafalski JA, Tingey SV (1993). Genetic analysis using random amplified polimorphic DNA markers. Meth Enzymol. 1218: 704-740.

Yae B, Ko K (1995).Classification of Malus domestica cultivars by random amplified polymorphic DNA markers. J. Korean Soc. Hortic. Sci., 36: 824-828. 